\title{
INFLUENCE OF PHOTOPERIOD ON THE ACCUMULATION OF ALLANTOIN IN COMFREY PLANTS
}

\author{
ANA HORTÊNCIA FONSÊCA CASTRO ${ }^{1}$, MARIA CLÁUDIA MARX YOUNG ${ }^{2}$, \\ AMAURI ALVES DE ALVARENGA ${ }^{2}$ AND JOSÉ DONIZETI ALVES ${ }^{1}$
}

\author{
Departamento de Biologia, Setor de Fisiologia Vegetal, Universidade Federal de Lavras.
}

\begin{abstract}
In order to evaluate the influence of photoperiod on the accumulation of allantoin in comfrey (Symphytum officinale L.), a well known medicinal plant, an experiment was conducted during July and August, 1998. Cuttings obtained from 90 day old plants were submitted to four photoperiods (8, 12,16 and 20 hours). After 60 days, allantoin content in roots and rhizomes was evaluated. The results showed that increases in photoperiod promoted an increment in the average content of allantoin in roots $(0.06 \%, 0.303 \%, 1.213 \%$ and $4.78 \%)$. On the other hand, in rhizomes, allantoin accumulation decreased $(9.65 \%, 7.14 \%, 0.55 \%)$ when the photoperiod was increased from 8 to 12 and 16 hours, respectively, stabilizing on a 20 -hour photoperiod $(0.53 \%)$. Plants cultivated under field conditions presented $2.55 \%$ and $2.63 \%$ allantoin content in rhizomes and roots, respectively. Based on the fact that in comfrey the roots are considered to be sites of allantoin synthesis, the results demonstrated that photoperiod could influence both the synthesis of allantoin in these organs as well as its accumulation in the rhizomes.
\end{abstract}

ADDITIONAL INDEX TERMS: HPLC, medicinal plant, secondary metabolism, Symphytum officinale, ureides.

\section{INFLUÊNCIA DO FOTOPERÍODO NO ACÚMULO DE ALANTOINA EM PLANTAS DE CONFREI}

RESUMO - Com o objetivo de avaliar a influência do fotoperíodo na produção e acúmulo de alantoína em plantas de confrei (Symphytum officinale L.), uma conhecida espécie medicinal, um experimento foi conduzido nos meses de julho e agosto de 1998. Mudas obtidas de plantas com 90 dias de idade foram submetidas a quatro fotoperíodos diferentes $(8,12,16$ e 20 horas) durante 60 dias, e os teores de alantoína em raízes e rizomas foram avaliados. Pelos resultados, constatou-se que fotoperíodos crescentes promoveram um aumento no teor médio de alantoína em raízes $(0,06 \%, 0,303 \%, 1,213 \%$ e 4,78\%) e uma redução no acúmulo de alantoína em rizomas $(9,65 \%, 7,14 \%$ e $0,55 \%)$, quando o fotoperíodo foi aumentado de 8 para 12 e 16 horas, respectivamente, tendendo a estabilizar-se em fotoperíodo de 20 horas $(0,53 \%)$. Plantas cultivadas em condições de campo apresentaram um teor de $2,55 \%$ e $2,63 \%$ de alantoína em rizomas e raízes, respectivamente. Tendo em vista que as raízes de confrei são consideradas sítios produtores de alantoína, pelos resultados, ficou demostrado que as condições de fotoperíodo influenciaram tanto a síntese dessa substância nesses órgãos, como o seu acúmulo nos rizomas.

TERMOS ADICIONAIS PARA INDEXAÇÃO: CLAE, metabolismo secundário, planta medicinal, Symphytum officinale, ureídeos.

Received: 26/8/2000 - Accepted: 21/3/2001

1. Departamento de Biologia, Setor de Fisiologia Vegetal, Universidade Federal de Lavras, Caixa Postal 37, 37.2000-000 Lavras - MG, Brazil. For correspondence: e-mail: acastro@ufla.br

2. Seção de Fisiologia e Bioquímica de Plantas, Instituto de Botânica, Caixa Postal 4.045, 01.061-970 - São Paulo - SP, Brasil. 
Castro et al.

\section{INTRODUCTION}

Symphytum officinale L. (Boraginaceae), known as comfrey, is a species widely used as a medicinal plant. It is employed as a tissue regenerator and its healing action is attributed to allantoin (Matos, 1994). The ureide allantoin has long been recognized as the major storage and translocation form of nitrogen in some plants (Bell and Webb, 1995) and these compounds are probably synthesized via purine degradation (Corpas et al., 1997). In Symphytum, allantoin can be found in the whole plant, although higher concentrations are observed in roots and rhizomes. Roots were considered to be the main site of ureide synthesis (Reinbothe and Mothes, 1962), even though leaves were also shown to synthesize these compounds when detached and kept in the dark (Hartmann and Arnold, 1974).

The allantoin concentration in comfrey varies according to the season, organ, physiological/developmental stage and nutritional state (Reinbothe and Mothes, 1962; Matsumoto et al., 1977; Saito and Oliveira, 1986) .

There is some indication that light is either directly or indirectly involved in ureide assimilation. Several reports have shown that allantoin and, more commonly, allantoate accumulate in dark-treated plants (Engelbrecht, 1955; Hartmann and Arnold, 1974). In Phaseolus vulgaris, ureides accumulated not only in green tissue, but also in the roots following dark treatment (Ceccato et al., 1998). The total amount of allantoin consists of two fractions, one supplied by metabolism in darkness, while the main part depends on light (Hartmann and Geissler, 1973). These authors suggested that purine degradation to allantoin involved two processes, one dependent on light and the other light-independent. In darkness allantoicase activity was inhibited and the single product of allantoin degradation is allantoic acid.

The objective of this work was to evaluate the effect of photoperiod on the patterns of allantoin accumulation in roots and rhizomes of comfrey plants.

\section{MATERIAL AND METHODS}

\section{Experimental conditions}

Comfrey cuttings obtained from 90 day old plants were transferred to plastic pots containing a subsoil, sand and manure mixture (2:1:1) as substrate. After initial development, the cuttings were transferred to growth chambers and submitted to the following photoperiod treatments: $8,12,16$ and 20 hours, with an average photosynthetic photon flux density of $200 \mu \mathrm{mol} \mathrm{s}-1$ $\mathrm{m}-2$ as determined by a 190SA quantum sensor, LI-COR, USA. During the experiment the soil was maintained close to its field capacity. Sixty days later, plants were harvested. The roots and rhizomes were washed in running tap water, separated and dried at room temperature for 2 days and then at 40 oC until constant weight was reached. In the next step, the samples were ground and stored in closed flasks protected from light, at room temperature.

\section{Extraction and analyses of allantoin and carbohydrates}

Approximately $500 \mathrm{mg}$ of the dried and ground material (roots and rhizomes) was mixed with $5 \mathrm{ml}$ of $80 \%$ ethanol and submitted to sonication for 15 minutes. The extract was filtered and $1 \mathrm{~mL}$ concentrated in a water bath, at $50 \mathrm{oC}$, under forced ventilation for 2 hours. The concentrate was dissolved with $1 \mathrm{~mL}$ of methanol:H2O (1:1), submitted again to sonication for 5 minutes and the volume made up to $10 \mathrm{~mL}$ with water. $1 \mathrm{~mL}$ of each sample was filtered through a Millex-HV filter $(0.45 \mu \mathrm{m}$ pore size, Millipore) and $40 \mu \mathrm{L}$ samples of each filtrate were injected into the HPLC column.

Stock solution of allantoin $\left(1 \mathrm{mg} \cdot \mathrm{mL}^{-1}\right)$ was prepared by dissolving pure standard (Sigma Chemical Co.) in water and storing at 4 oC for 1 month. Working standard solutions ranging from 1 to $200 \mu \mathrm{g} / \mathrm{mL}$ were prepared by dilution to establish a calibration curve. The quantification was achieved by regression analysis of the peak 
areas against standard concentrations. Triplicate injections of each concentration were made.

HPLC analyses were performed in a Dionex DX500 device with Diode Array detector and the samples were analyzed through a $4.6 \mathrm{~mm} \mathrm{x}$ $250 \mathrm{~mm}$ Zorbax ODS C-18 column. The mobile phase consisted of $10 \mathrm{mM}$ potassium phosphate buffer $\left(\mathrm{KH}_{2} \mathrm{PO}_{4}\right), \mathrm{pH}$ 4.0. The flow rate was 0.5 $\mathrm{mLm}^{-1}$ at room temperature and the absorbance detector was set at $218 \mathrm{~nm}$, in the isocratic mode. Allantoin peaks were identified by their retention time and coelution with the authentic standard and quantified by comparing the peak areas of samples with those of authentic standard.

Starch was extracted following the LaneEnyon hydrolytic method, described in AOAC (1970), and total soluble carbohydrates (TSC) according to the technique of Arêas and Lajolo (1980). Both were determined colorimetrically using the anthrone reaction (Dische, 1962).

\section{Experimental design and statistical analysis}

The experiment was carried out in a completely randomized design, with 4 photoperiodic treatments $(8,12,16$ and 20 hours) and 3 replications. The extracts for determination of allantoin content, TSC and starch were obtained from a mixed root or rhizome sample of each individual plant ( $\mathrm{n}=3$ plants at each photoperiod). The results were submitted to variance analysis and the significant treatment differences were assessed based on Tukey's studentised range test ( $\mathrm{P}$ $<0.05$ ), according to Gomes (1990).

\section{RESULTS AND DISCUSSION}

The retention time for allantoin was $c a$. 6.13 min (Figures 1 and 2). A linear relationship between the peak area and the allantoin concentration in samples was obtained for the range of concentrations used $(1-200 \mu \mathrm{g} / \mathrm{mL})$.

Increase of the photoperiod promoted a progressive increment in the allantoin content in roots and a drastic reduction in the rhizomes (Figure 3). Comfrey plants maintained on the 20hour photoperiod showed a root allantoin content $c a$. eighty-fold higher than plants submitted to the 8-hour photoperiod. In rhizomes, the allantoin accumulation was $c a$. eighteen-fold lower in the 20-hour photoperiod than that presented by plants cultivated under the 8-hour photoperiod. The results clearly revealed some distinctive features of the metabolic status of comfrey and the possibility of manipulation of photoperiodic conditions to enhance the commercial value of this species.
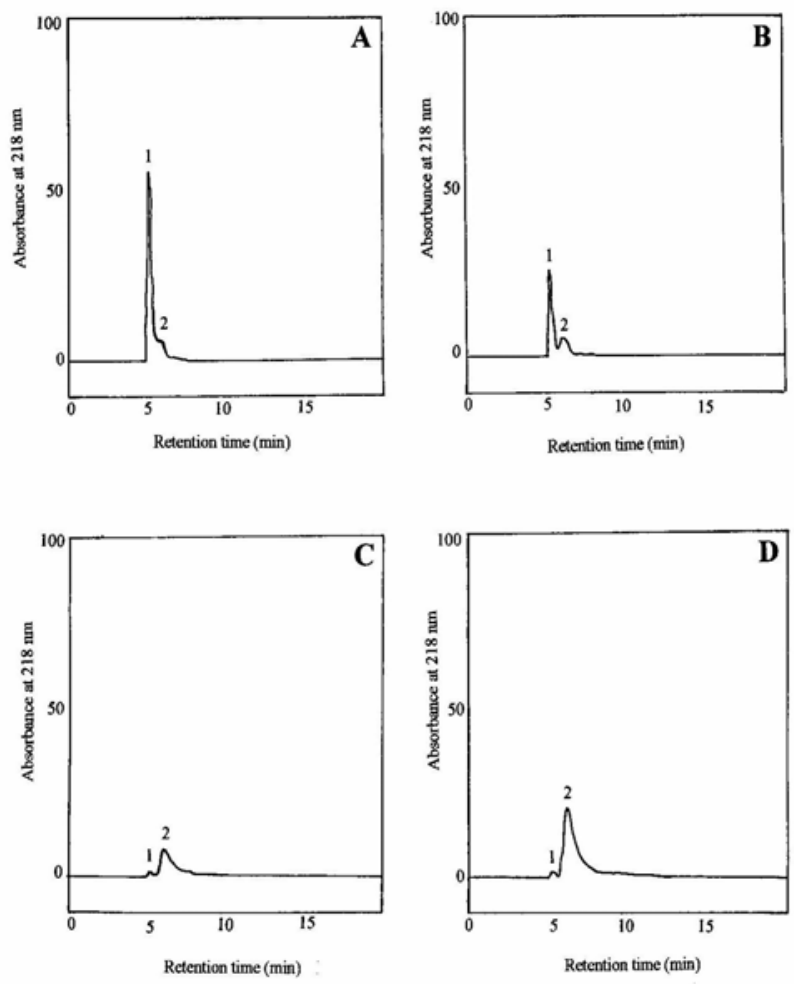

FIGURE 1 - Effect of different photoperiods on the allantoin levels in roots of comfrey plants. A) 8 hours; B) 12 hours; C) 16 hours; D) 20 hours; Peak $1=$ non-characterized substance; Peak $2=$ allantoin.

The effects of photoperiod on the accumulation of many secondary metabolites have been reported in other species. In Origanum syriacum (Dudai et al., 1992) the relative content 
of hydrocarbon terpenes was higher in plants grown on short-days (51\%) compared with those grown on long-day cycles $(28 \%)$. On the other hand, the relative phenolic monoterpene content was higher in plants grown on long days (59\%) than in plants grown on short days (38\%). Suchorska et al., (1992) showed that the Artemisia drancunculus $f$. drancunculus mass and essential oil content were markedly higher in plants growing under long days $(16 \mathrm{~h})$. Various aromatic species exposed to a 21-hour photoperiod produced significantly higher concentrations of menthol $(2,7 \%)$ than treatments with shorter photoperiods (1,2\%) (Fahlén et al., 1997).
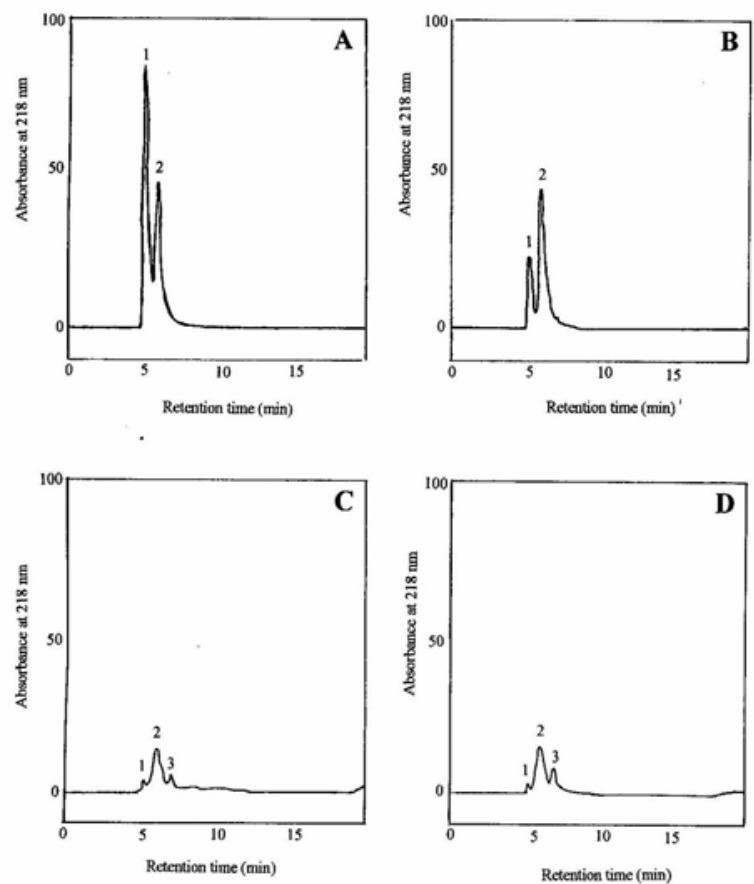

FIGURE 2 - Effect of different photoperiods on the allantoin levels in rhizomes of comfrey plants. A) 8 hours; B) 12 hours; C) 16 hours; D) 20 hours. Peak 1 and $3=$ non-characterized substance; Peak 2 = allantoin.

Regulation of ureide metabolic pathway enzymes in higher plants is poorly understood. There is some indication that light is either directly and indirectly involved in ureide assimilation.
Classical reports have shown that allantoin accumulates in dark-treated plants (Engelbrecht, 1955; Van der Drift and Vogels, 1966; Hartmann and Arnold, 1974). Ceccato et al. (1998) observed in Phaseolus vulgaris that ureides accumulated not only in green tissues but also in the roots following dark treatment. Hartmann and Geissler (1973) suggested that purine degradation to allantoin involved two steps, one dependent on light and the other light-independent. In darkness, allantoicase activity is inhibited (Montalbini, 1992) so the allantoate produced by allantoin degradation is not converted into glyoxylate and urea and thus accumulates (Thomas and Schrader, 1981).

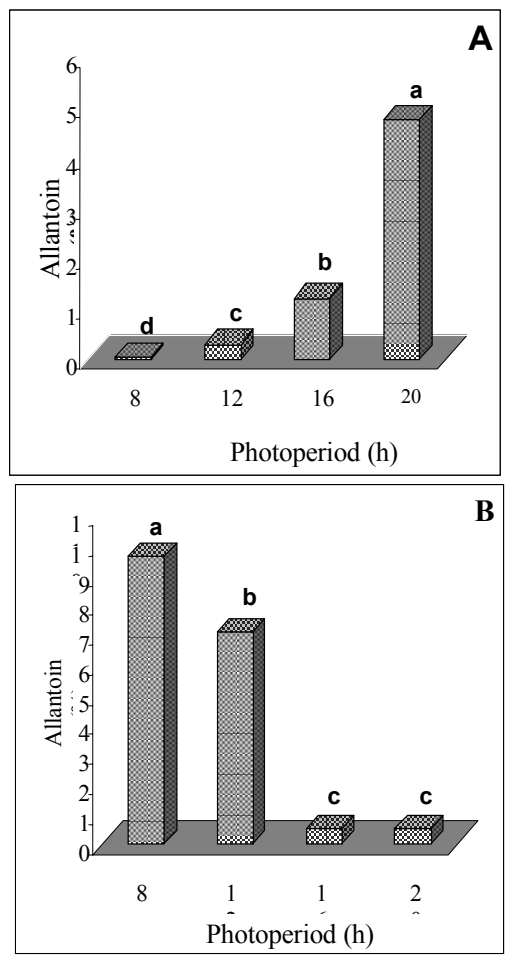

FIGURE 3 - Effect of different photoperiods on the allantoin accumulation in comfrey plants. A) roots; B) rhizomes.

The analysis of starch in comfrey plants showed maximum root starch content on the 8hour photoperiod and an accentuated decrease on the 20-hour photoperiod (Figure 4). On the other 
hand, the TSC content of roots was enhanced as the photoperiod increased (Figure 4). The results suggest that the longer the photoperiod, the higher are the TSC concentrations in roots and the more
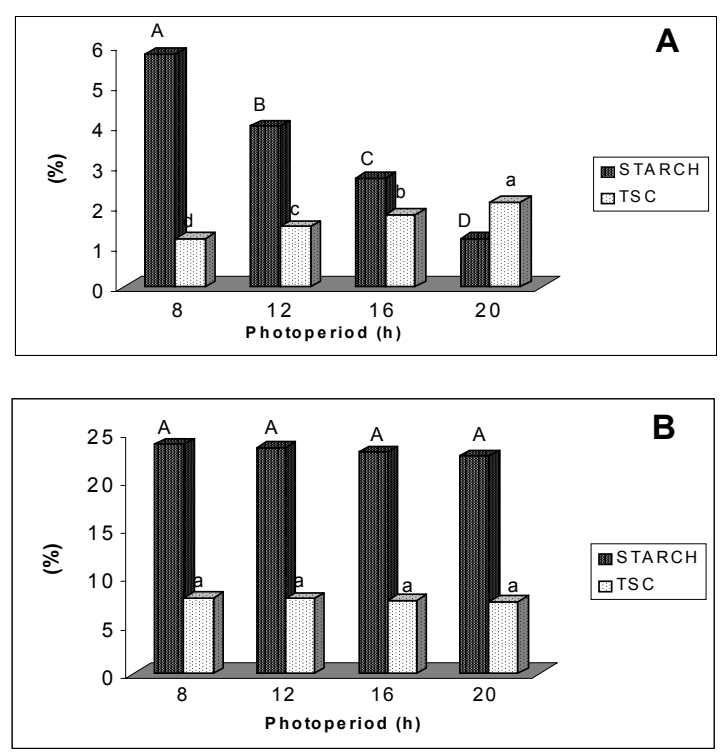

FIGURE 4 - Levels of starch and total soluble carbohydrates (TSC) in comfrey plants on different photoperiods. A) roots; B) rhizomes. Means followed by the same letter are not significantly different by the Tukey test at the $5 \%$ level.

intense the catabolism of accumulated starch in this organ, supplying it with the precursor substances for the allantoin metabolic pathway. Therefore, our results indicate that, in comfrey, the roots can be a site of allantoin synthesis, in agreement with the results from Reinbothe and Mothes (1962). For Hartmann and Arnold (1974), the enzyme allantoinase presents low activity in roots, coincident with the greater accumulation of allantoin in this organ (Figure 3). Nevertheless, the results disagree with those obtained by Engelbrecht (1955), Van der Drift and Vogels (1966) and Hartmann and Arnold (1974), who suggested that allantoin and, more commonly, allantoic acid accumulate in dark-treated plants.
Variation in the levels of TSC and starch was not observed in rhizomes (Figure 4). Although this organ accumulates starch, probably it is unable to produce allantoin. This suggests that allantoin observed in rhizomes is provided by translocation from other organs (roots and/or leaves). The decrease of allantoin levels in this site with the increase of the photoperiod is probably a consequence of the increase in the activity of the enzyme allantoinase with light, as reported by Engelbrecht (1955) and Ceccato et al. (1998) for Phaseolus vulgaris.

\section{REFERENCES}

ARÊAS, J.A.G.; \& LAJOLO, F.M. Determinação enzimática específica de amido, glicose, frutose e sacarose em bananas preclimatéricas e climatéricas. Anais de Farmácia e Química de São Paulo, 20: 307-318, 1980.

ASSOCIATION OF OFFICIAL ANALYTICAL CHEMISTS. Official methods of the association of official analytical chemists. Washington, Academic Press, 1970. 112 p.

BELL, J.A.; \& WEBB, M.A. Immunoaffinity purification and comparison of allantoinases from soybean root nodules and cotyledons. Plant Physiology, 107, 435-441, 1995.

CECCATO, V.M.; GOMES, J.E.; SARRIES, G.A.; MOON, D.A; \& TSAI, S.M. Effects of host plant origin on nodulin activites and nitrogen fixation in Phaseolus vulgaris L.

Plant Soil, 204: 79-87, 1998.

CORPAS, F.J.; COLINA, C. DE LA; SANCHEZRASERO, F.; \& RIO, L.A. DEL Metabolism of activated oxygen in peroxisomes from two Pisum sativum L. cultivars with different sensitivity to sodium chloride. Journal of Plant Physiology, 151: 246-250, 1997. 
DISCHE, Z. General color reaction. In: WHISTER, R.L.; WOLFRAM, M.L., eds. Carbohydrate chemistry. New York, Academic Press, 477-512, 1962.

DUDAI, N.; PUTIEVSKY, E.; RAVID, U.; PALEVITCH, D.; \& HALEVY, A.H. Monoterpene content in Origanum syriacum as affected by environmental conditions and flowering. Physiologia Plantarum, 84: 453459, 1992.

ENGELBRECHT, L. Über allantoinsäure und allantoin. IV. Ihre beziehungen $\mathrm{zu}$ den säureamiden bei der keimung von Phaseolus vulgaris L. Flora Oder Allgemeine Botanische Zeitung, 142: 25-44, 1955.

FAHLÉN,A.; WELANDER, M.; \& WENNERSTEN, R. Effects of lighttemperature regimes on plant growth and essential oil yield of selected aromatic plants. Journal of Science Food and Agriculture, 73: 111-119, 1997.

GOMES, F.P. Curso de Estatística Experimental. 13 ed. Piracicaba: Nobel, 1990. 468 p.

HARTMANN, V.E.; \& ARNOLD, G. Über den ureidstoffwechsel beim laubmoosprotonema von Funaria hygrometrica L. (SIBTH.). III. Einfluss von licht und dunkelheit auf die aufnahme und den umsatz von allantoin- $7-{ }^{14} \mathrm{C}$. Biochemie und Physiologie der Pflanzen, 166: 57-72, 1974.

HARTMANN, V.E.; \& GEISSLER, G. Über den ureidstoffwechsel beim laubmoosprotonema von Funaria hygrometrica L. (SIBTH.). I. Der einfluss von verschiedenfarbigem licht. Biochemie und Physiologie der Pflanzen, 164: 614-622, 1973.
MATOS, F.J.A. Farmácias vivas: sistema de utilização de plantas medicinais projetado para pequenas comunidades. 2.ed. Fortaleza: UFC, 1994. $180 \mathrm{p}$.

MATSUMOTO, T.; YATAZAWA, M.; \& YAMAMOTO, Y. Distribution and change in the contents of allantoin and allantoic acid in developing nodulating and non-nodulating soybean plants. Plant and Cell Physiology, 18: 353-359, 1977.

MONTALBINI, P. Ureides and enzymes of ureide synthesis in wheat seeds and leaves and effects of allopurinol on Puccinia recondita f. sp. tritici infection. Plant Science, 87, 225-231, 1992.

REINBOTHE, H.; \& MOTHES, K. Urea, ureides and guanidines in plants. Annual Review of Plant Physiology, 13: 129-150, 1962.

SAITO, M.L.; \& OLIVEIRA, F. Características físicas e químicas do extrato fluido de Cordia ecalyculata Vell. - Boraginaceae. Revista Brasileira de Farmacognosia, 1: 3-11, 1986.

STEBBINS, N.E.; \& POLACCO, J.C. Urease is not essential for ureide degradation in soybean. Plant Physiology, 109 (1), 169-175, 1995.

SUCHORSKA, K.; JEDRASZKO, B.; \& OLSZEWSKA-KACZYNSKA, I. Influence of daylength on the content and composition of the essential oil from taragon (Artemisia dracunculus $f$. dracunculus). Annals of Warsaw Agricultural University, 16: 79-82, 1992.

THOMAS, R.J.; \& SCHRADER, L.E. Ureide metabolism in higher plants. Phytochemistry, Oxford, 20: 361- 371, 1981.

VAN DER DRIFT, C.; \& VOGELS, G.D. Allantoin and allantoate in higher plants. Acta Botanica Neerlandica, 15: 209-214, 1966. 